\title{
Intramedullary Tuberculoma after Tuberculous Meningitis -A Rare Case with an Uncommon Radiological Presentation
}

\section{Tuberculoma intramedular secundário à meningite tuberculosa-um caso raro com apresentação radiológica incomum}

\author{
Pedro Radalle Biasi ${ }^{1}$ Matheus Balen ${ }^{2}$ Timóteo Abrantes de Lacerda Almeida ${ }^{1}$ \\ Rafael Augusto Espanhol ${ }^{1}$ Matheus Pintos Brunet ${ }^{1}$ Wellington César de Souza ${ }^{1}$ \\ Eduardo Felipe Martinelli Baldissera ${ }^{1}$ Paulo Sérgio Crusius ${ }^{3}$ Cláudio Albano Seibert ${ }^{3}$ \\ Marcelo Ughini Crusius ${ }^{3}$ Cassiano Ughini Crusius ${ }^{3}$ Adroaldo Baseggio Mallmann ${ }^{3}$ \\ Charles André Carazzo 3 \\ 1 Department of Neurosurgery, São Vicente de Paulo Hospital, Passo \\ Fundo, Rio Grande do Sul, Brazil \\ 2 Faculty of Medicine, Universidade Passo Fundo, Passo Fundo, Rio \\ Grande do Sul, Brazil \\ 3 Institute of Neurology and Neurosurgery, Hospital São Vicente de \\ Paulo, Passo Fundo, Rio Grande do Sul, Brazil \\ Address for correspondence Pedro Radalle Biasi, MD, Av. Sete de \\ Setembro, 65, apto 101, Passo Fundo, RS, Brazil CEP 99010-121 \\ (e-mail: pedrobiasi@doctor.com). \\ São Vicente de Paulo Hospital, Passo Fundo, Brazil. \\ Arq Bras Neurocir 2015;34:166-169.
}

\begin{abstract}
Tuberculosis is a chronic bacterial infection caused by Mycobacterium tuberculosis. Despite advances in treatment, resistant strains and unusual sites of involvement have been diagnosed. We present a case of a 13-year-old patient in treatment for tuberculous meningitis who presented with progressive paraparesis. The MRI showed two intramedullary nodular lesions at T4-T6 levels, isointense with annular hyperintensity on T1W, hypointense on T2W, becoming hypointense with ring enhancement after contrast. These characteristics differ from those usually described for intramedullary tuberculomas. Surgical excision was performed, confirming the diagnosis of intramedullary tuberculoma. The formation of intramedullary tuberculomas is rare, with a ratio of two cases per thousand diagnosed with CNS tuberculosis, and the thoracic spine is most frequently affected. The clinical picture is of progressive subacute spinal cord compression, and it may lead to paraplegia. At MRI, the lesion in early stage

Keywords

- tuberculosis

- tuberculous meningitis

- intramedullary tuberculoma appears as hypointense rings on T1W and hyperintense on $\mathrm{T} 2 \mathrm{~W}$, with homogeneous enhancement after contrast. After the formation of the solid caseous granuloma, it becomes isointense on T1W and hypointense on T2W with homogeneous enhancement after contrast. When the center of the granuloma becomes liquefied, it shows hypointense sign on T1W and hyperintense with peripheral enhancement on T2W. The treatment of choice is medical, with the current protocol including rifampin, isoniazid, pyrazinamide, and ethambutol. Surgery is reserved for cases of progressive neurologic
\end{abstract}

received

July 7, 2014

accepted

March 31, 2015
DOI http://dx.doi.org/ $10.1055 / \mathrm{s}-0035-1554901$ ISSN 0103-5355.
Copyright $\odot 2015$ by Thieme Publicações License terms Ltda, Rio de Janeiro, Brazil

(c) $(1) \$$ 


\section{Resumo}

\section{Palavras-chave}

- tuberculose

- meningite tuberculosa

- tuberculoma intramedular

- tuberculoma medular deficits or for diagnostic confirmation. Although benign and potentially curable, intramedullary tuberculoma should be promptly diagnosed and treated to prevent irreversible damage.

A tuberculose é uma infecção bacteriana crônica causada pelo Mycobacterium tuberculosis. Apesar dos avanços no tratamento, cepas resistentes e locais incomuns de envolvimento vêm sendo diagnosticados. Apresentamos o caso de um paciente de 13 anos de idade, em tratamento para meningite tuberculosa que se apresentou com paraparesia progressiva. A ressonância magnética mostrou duas lesões nodulares intramedulares no nível de T4-T6, isointensas com bordos hiperintensos em T1, hipointensos em T2, tornando-se hipointensos com realce anelar após contraste. Essas características diferem daquelas usualmente descritas para tuberculomas intramedulares. Foi realizada a excisão cirúrgica, confirmando o diagnóstico de tuberculoma intramedular. A formação de tuberculomas intramedulares é rara, com uma proporção de dois casos por mil diagnosticados com tuberculose do sistema nervoso central (SNC), e a coluna torácica é a mais frequentemente acometida. O quadro clínico é de compressão da medula espinal progressiva subaguda, podendo levar à paraplegia. $\mathrm{Na}$ ressonância magnética, a lesão em fase inicial aparece como anéis hipointensos em T1 e hiperintensos em T2, com realce homogêneo após contraste. Após a formação do granuloma caseoso sólido, torna-se isointensa em T1 e hipointensa em T2, com realce homogêneo após contraste. Quando o centro do granuloma torna-se liquefeito, mostra sinal hipointenso em $\mathrm{T} 1$ e hiperintenso com realce periférico em T2. O tratamento de escolha é medicamentoso, com o protocolo corrente de rifampicina, isoniazida, pirazinamida e etambutol. A cirurgia é reservada para os casos de déficit neurológico progressivo ou para confirmação diagnóstica. Embora benigna e potencialmente curável, deve ser diagnosticada e tratada para evitar danos irreversíveis.

\section{Background}

Tuberculosis is a chronic bacterial infection caused by Mycobacterium tuberculosis. It is a globally disseminated disease, remaining endemic in developing countries, predominantly in immunocompromised patients, especially human immunodeficiency virus (HIV)-positive, chronic, and cancer patients. ${ }^{1-5}$ Despite advances in the field, resistant strains have been identified and unusual sites of tissue involvement are being diagnosed more often. The first report of intramedullary tuberculoma dates back to 1828 and it was described by Abercrombie $\left(\right.$ apud $\left.^{2}\right)$.

The authors present the case of an adolescent patient, immunocompetent, which showed intramedullary tuberculoma during treatment for tuberculous meningitis.

\section{Case Report}

We present an unusual case of intramedullary tuberculoma with uncommon radiographic findings in 13-year-old with resistant tuberculous meningitis confirmed by polymerase chain reaction, in treatment with streptomycin, ethambutol, levofloxacin, pyrazinamide, and terizidone, which began with progressive paraparesis over 1 week, culminating with spastic paraplegia. The magnetic resonance imaging (MRI) showed two intramedullary lesions at the level of
T4-T6, with nodular appearance, isointense signal on T1W with slight hyperintense halo ( $\mathbf{F i g . ~ 1 )}$ ), and hypointense on T2W (-Fig. 2), becoming isointense with hyperintense ring enhancement after infusing the contrast ( - Fig. 3). A surgical excision was performed with histologic results confirming intramedullary tuberculoma.

\section{Discussion}

The central nervous system (CNS) involvement in infection caused by M. tuberculosis, much feared because of its high rates of morbidity and mortality, is uncommon even in endemic areas, accounting for about 0.5 to $2 \%$ of cases of systemic tuberculosis. ${ }^{1,2,4-7}$ Among these, spinal cord injuries occur in less than $8 \%$ of patients, and tuberculomas, even rarer, occur in 2 cases per 100,000 diagnosed with systemic tuberculosis, and 1,000 with CNS tuberculosis. ${ }^{2,3,6-10}$ Pott disease, spinal arachnoiditis, and other lesions appear more frequently. The thoracic spine accounts for $72 \%$ of spinal cases, and in $69 \%$ of cases there is concomitant pulmonary tuberculosis. ${ }^{1-3,5,6,8} \mathrm{Com}-$ pared with cerebral damage, spinal cord injury occurs in a proportion of $1 / 42$, the data that relate to the ratio of spinal cord and brain weight, which is $1 / 47$, suggesting a relationship between infectivity and density of neural tissue. ${ }^{6,7,9}$

The formation of tuberculoma, in most cases, is induced by hematogenous spread from a systemic focus of 


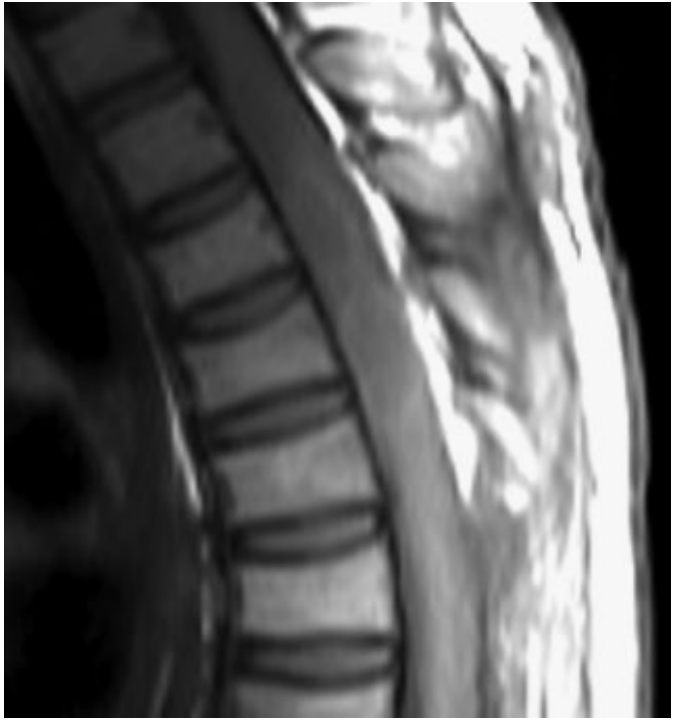

Fig. 1 Sagittal T1W magnetic resonance imaging (MRI) shows two hypointense nodular lesions, with mild annular hyperintensity at T4-T6 levels.

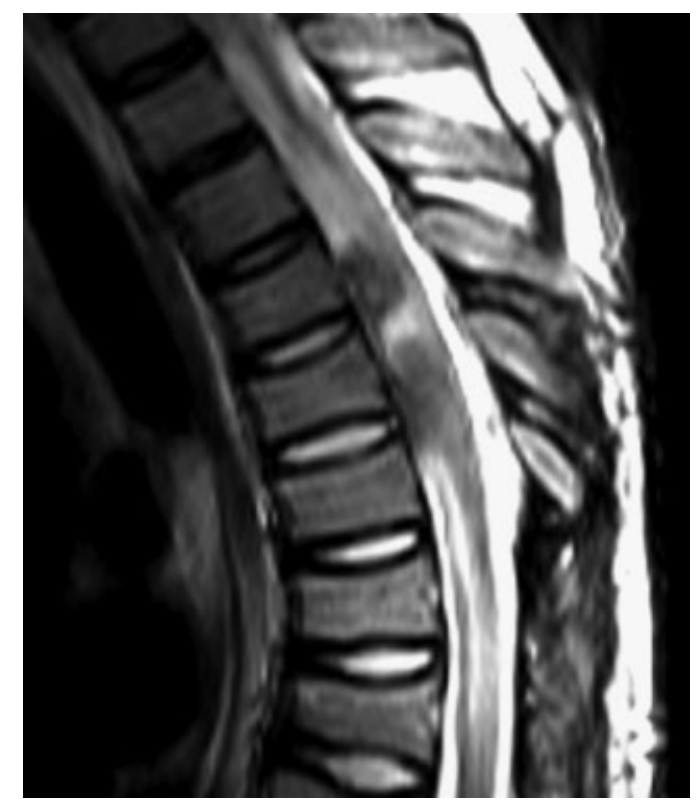

Fig. 2 Sagittal T2W magnetic resonance imaging (MRI) shows two homogeneous hypointense nodular lesions at T4-T6 level.

tuberculosis and, more rarely, by direct contamination of neural tissue through cortical veins and penetrating artery in cases of tuberculous meningitis, as described by many authors. ${ }^{5,9,10}$

The clinical presentation is marked by progressive subacute spinal cord compression with weakness in the lower limbs, which may cause flaccid or spastic paraplegia, paresthesias, urinary and fecal incontinence, and sensory level. ${ }^{6,8}$ By being unspecific, physicians should be aware for possible differential diagnoses such as spinal tumors and Pott disease, more common than tuberculoma.

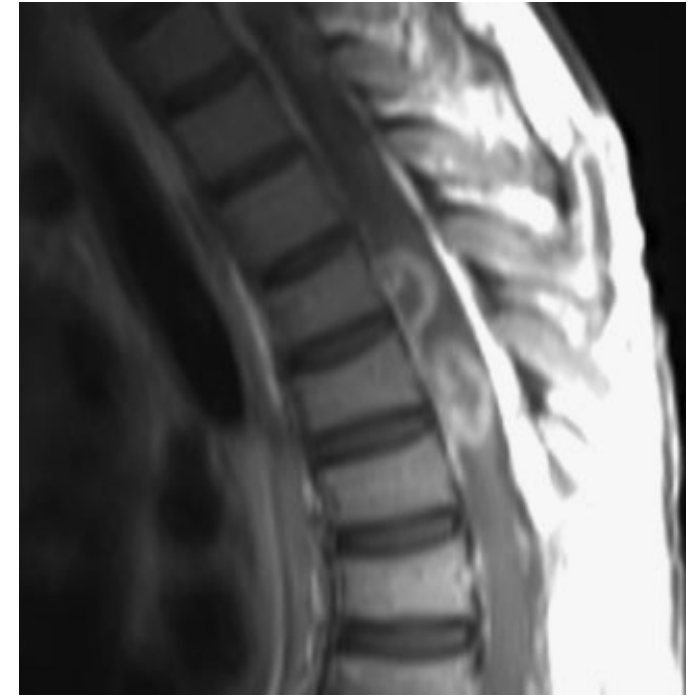

Fig. 3 Sagittal T1W with contrast shows the ring enhancement of the two lesions.

The radiographic aspect of these lesions correlates with the stage of maturation of the granuloma. In the early stages the peritumoral edema is higher due to the absence of fibrotic capsule, which decreases while the lesion progresses. Thus, it appears as hypointense rings in relation to the medullary parenchyma on $\mathrm{T} 1 \mathrm{~W}$ and hyperintense on $\mathrm{T} 2 \mathrm{~W}$, with homogeneous enhancement after contrast. As it becomes a solid caseous granuloma, the signal intensity changes, being isointense on $\mathrm{T} 1 \mathrm{~W}$ and hypointense on $\mathrm{T} 2 \mathrm{~W}$, with homogeneous enhancement after contrast. When it becomes liquefied, the center of the granuloma shows hypointense signal on T1W and hyperintense on T2W, with ring enhancement. ${ }^{3-6,8,9}$ Thus, we perceive the difference between the radiographic pattern of tuberculoma and the evidence in the author's case, which makes the diagnosis and therapeutic decision a challenge.

In general, the various forms of tuberculosis had good response to medical treatment, this being of choice when the spinal cord injury is a known tuberculoma. However, surgical intervention is not ruled out, especially in cases of progressive neurologic deficits, where excision of the lesion associated with drug treatment presents better outcomes. ${ }^{8,10,11}$ Still, the intervention for diagnostic confirmation or even for palliative procedures may be required. The national protocol currently has four drugs: rifampicin, isoniazid, pyrazinamide, and ethambutol for a period of 9 months; however, resistant cases have emerged and new associations are being formed, like in this article's case. $^{12}$

This report shows an unusual form of occurrence of intramedullary tuberculoma associated with radiologic aspects different of the usual pattern, which makes the diagnosis and treatment complex and alert to its inclusion in the differential diagnosis of tumor spinal cord injuries. 


\section{References}

1 Balasa D, Tunas A, Terzi A, Serban C, Aschie M. Primary tuberculomas of the thoracal spinal cord-case report. Romanian Neurosurg 2012;19(Suppl 1):63-66

2 Pérez CE, Calderón CM, Bohórquez L. Intramedullary tuberculoma in an immunocompetent patient. Infection 2011;15 (Suppl 2):124-128

3 Kotil K, Guzel N. Primary intramedullary tuberculoma of the spinal cord mimicking to spinal cord tumor. J Neurol Sci 2006; 23:63-67

4 Muthukumar N, Venkatesh G, Senthilbabu S, Rajbaskar R. Surgery for intramedullary tuberculoma of the spinal cord: report of 2 cases. Surg Neurol 2006;66(Suppl 1):69-74, discussion 74

5 Arslantas A, Faruk A, Kismet B, Esref T. Intramedullary tuberculoma of the spinal cord. J Postgrad Med 2002;48(1):54-55

6 Kayaoglu CR, Tuzun Y, Boga Z, Erdogan F, Gorguner M, Aydin IH. Intramedullary spinal tuberculoma: a case report. Spine 2000; 25(17):2265-2268
7 Lu M. Imaging diagnosis of spinal intramedullary tuberculoma: case reports and literature review. J Spinal Cord Med 2010;33 (Suppl 2):159-162

8 Devi BI, Chandra S, Mongia S, Chandramouli BA, Sastry KV, Shankar SK. Spinal intramedullary tuberculoma and abscess: a rare cause of paraparesis. Neurol India 2002;50(4):494-496

9 Bashir S, Memon AA, Sanaullah M, Hasan Y. Intra-medullary tuberculoma of the spinal cord presenting with typhoid and paraplegia: a case report. J Med Case Reports 2012;6:388

10 Shah IU, Siddiqui UT, Imran M, Ashraf J, Mazhar S, Ghori SA. Intramedullary spinal tuberculoma. J Coll Physicians Surg Pak 2012;22(Suppl 1):48-49

11 Bhatoe HS. Intramedullary spinal cord tuberculoma case report. Ind J Tub 1996;43:99-100

12 Conde MB, Melo FA, Marques AM, et al; BTA Committee on Tuberculosis; BTA Guidelines on Tuberculosis Work Group. III Brazilian Thoracic Association Guidelines on tuberculosis. J Bras Pneumol 2009;35(10):1018-1048 